\title{
Symbiosis of epi- and endocuticular bacteria with Helicoradomenia spp. (Mollusca, Aplacophora, Solenogastres) from deep-sea hydrothermal vents
}

\author{
Sigrid Katz $^{1, *}$, Colleen M. Cavanaugh ${ }^{2}$, Monika Bright ${ }^{1}$ \\ ${ }^{1}$ Department of Marine Biology, Faculty of Life Sciences, University of Vienna, Althanstr. 14, 1090 Vienna, Austria \\ ${ }^{2}$ Department of Organismic and Evolutionary Biology, Harvard University, 16 Divinity Avenue, Cambridge, \\ Massachusetts 02138, USA
}

\begin{abstract}
Two species of Solenogastres (Mollusca, Aplacophora) from deep-sea hydrothermal vents of the East Pacific Rise, Helicoradomenia cf. acredema and a second as yet undescribed species of the same genus, were discovered to harbor epibiotic and endocuticular prokaryotes along their entire bodies. Helicoradomenia sp. 1 additionally harbored intracellular rods in the epidermis. TEM (transmission electron microscopy) and SEM (scanning electron microscopy) observations revealed 4 different bacterial morphotypes: rod-shaped, helical, unsheathed and sheathed trichomes. One conspicuous rod was found to contain membranes typical for type II methanotrophs. Applying in situ hybridization with group-specific Bacteria and Archaea probes, the majority of the prokaryotes associated with Helicoradomenia sp. 1 were identified as $\alpha$-Proteobacteria, while others belonged to the $\gamma$-Proteobacteria or could not be associated with a definite bacterial clade. While solenogastres usually lack microbial epigrowth, the 2 Helicoradomenia species consistently are associated with similar epi- and endocuticular bacteria, indicating these are symbiotic associations.
\end{abstract}

KEY WORDS: Symbiosis · Helicoradomenia · Solenogastres · Alphaproteobacteria · Gammaproteobacteria $\cdot$ Hydrothermal vents $\cdot$ East Pacific Rise $\cdot$ Chemosynthesis $\cdot$ Aplacophora

\section{INTRODUCTION}

Although deep-sea hydrothermal vents and their associated fauna were discovered almost $30 \mathrm{yr}$ ago (Lonsdale 1977, Corliss 1979), we are still not completely acquainted with this unique ecosystem and new discoveries are being made continuously. These exceptional habitats became well known for remarkable symbioses between chemosynthetic bacteria and invertebrates, which flourish there in high numbers. One of the most prominent inhabitants is Riftia pachyptila Jones, 1981 (Siboglinidae, Polychaeta), the giant tubeworm, that lives in symbiosis with sulfideoxidizing, chemolithoautotrophic (thioautotrophic) bacteria (Cavanaugh et al. 1981, Felbeck 1981). These symbionts, belonging to the $\gamma$-Proteobacteria, are located inside the worm within a special organ, the trophosome, and nourish the whole mollusk (McMullin et al.
2003, Bright \& Giere 2005, Cavanaugh et al. 2005). However, in addition to numerous endosymbiotic associations, epibiotic symbioses have also been discovered. For example, the polychaete Alvinella pompejana Desbruyères and Laubier, 1980, which lives within tubes in the high temperature zone on black smoker chimneys, is colonized by a diverse epibiotic community (Desbruyères et al. 1998). Its dominant filamentous bacteria are members of the $\varepsilon$-Proteobacteria (Haddad et al. 1995, Cary et al. 1997, Campbell \& Cary 2001, Campell et al. 2001). Similarly, Rimicaris exoculata Williams and Rona, 1986, a decapod shrimp from the Mid-Atlantic Ridge, also hosts epibiotic bacteria belonging to the $\varepsilon$-Proteobacteria (Polz \& Cavanaugh 1995, Polz et al. 1998).

Endosymbioses between mollusks and prokaryotes from reducing shallow and deep sea habitats, including hydrothermal vents, have been described in a 
number of bivalves and gastropods (Cavanaugh et al. 2005). These gram-negative endosymbionts are located in specialized cells within the gills. Some of those bivalves host only thioautotrophs, while others have established a dual symbiosis hosting both thioautotrophic as well as methanotrophic bacteria. The majority of these endosymbionts known so far belong to the $\gamma$-Proteobacteria (Cavanaugh et al. 20005), yet the endosymbionts in Alvinichoncha sp. type I from the Manus Basin have recently been identified as $\gamma$-Proteobacteria (Urakawa et al. 2005). Also, a new species of gastropod (Neomphalina, Peltospiridae) harboring endosymbiotic $\gamma$-Proteobacteria as well as ectosymbiotic $\varepsilon$ - and $\delta$-Proteobacteria, has been described from vents on the Central Indian Ridge (Goffredi et al. 2004).

Solenogastres, worm-like aplacophoran mollusks, have a reduced foot and are known to lack a continuous shell or plate. They possess calcareous spicules embedded in and protruding above their cuticle, and are therefore placed at the base of the Mollusca phylogenetic tree. The cuticle of Solenogastres is composed of a glycoprotein complex with high acid mucopolysaccharides, low protein, and chitin (Beedham \& Trueman 1968, Peters 1971). Both the cuticle and the spicules are a product of the epidermis (Scheltema et al. 1994). The spicules are transported outwards together with older cuticlar material as new cuticula is being secreted. Most Solenogastres keep their surface clean from any microbial growth, as no prokaryotes have been detected in light microscopy and transmission electron microscopy sections of many different species (L. Salvini-Plawen pers. comm.). Only in Neomenia carinata have bacterial associations been observed (Scheltema et al. 1994).

The genus Helicoradomenia has only been described from hydrothermal vents and its 3 described species (Scheltema 1991, 2000) and 1 as yet undescribed species (here termed Helicoradomenia sp. 1) (C. Todt pers. comm.) are among the most common Solenogastres at such sites. Representatives of this genus are found at hydrothermal systems from the eastern and western Pacific as well as at vents on the Central Indian Ridge (Scheltema 2000, Van Dover et al. 2001, Van Dover 2002). H. cf. acredema Scheltema, 2000 can reach up to $3 \mathrm{~mm}$ in length (Scheltema 2000). The mollusks have a fully developed digestive tract, and it has been suggested that they are scavengers feeding on small polychaetes (Todt \& Salvini-Plawen 2005). Their epidermis is about $14 \mu \mathrm{m}$ thick and secretes a $22 \mu \mathrm{m}$ thick cuticle into which calcareous spicules are embedded (Scheltema 2000). During microscopic examination of $H$. cf. acredema and Helicoradomenia sp. 1 while at sea, both species had a conspicuous white color and upon close examination microbial gro- wth was detected on their cuticle and on the spicules protruding above the cuticle. Since invertebrates living in symbiosis with thioautotrophic bacteria often look white due to elemental sulfur inclusions in their symbionts (Krieger et al. 2000, Pflugfelder et al. 2005), the conspicuous white color of $H$. cf. acredema and Helicoradomenia sp. 1 and the nature of the mollusks' habitat suggest the existence of a similar association.

The present study characterizes and compares the association between these 2 species of Solenogastres and prokaryotes, examining where the prokaryotes are located on the mollusks, how they are distributed, as well as their morphology and ultrastructure. Further, using Bacteria and Archaea domain-specific and several Bacteria group-specific oligonucleotide probes, we determined the phylogenetic divisions of the symbionts.

\section{MATERIALS AND METHODS}

Artificial settlement devices were deployed at a depth of $2500 \mathrm{~m}$ (Dive \#3738) on December 24, 2001, during the DSV 'Alvin' cruise 'Holidays at Sea' at the East Pacific Rise, at the hydrothermal vent site TICA $\left(9^{\circ} 50.447^{\prime} \mathrm{N}, 104^{\circ} 17.493^{\prime} \mathrm{W}\right)$. Such devices were deployed within a Riftia pachyptila aggregation and less than a meter away from an aggregation on bare basalt with ambient deep-sea temperatures of $2^{\circ} \mathrm{C}$. The devices were recovered during the 'Another Holiday at Sea' cruise on December 1, 2002 (Dive \#3843) and on December 4, 2002 (Dive \#3846). Approximately 100 specimens were collected.

Scanning electron microscopy (SEM). Helicoradomenia cf. acredema and Helicoradomenia sp. 1 individuals were collected from artificial settlement devices collected in 2002, fixed in a mixture of $1.5 \%$ acrolein, $3 \%$ glutaraldehyde, and $1.5 \%$ paraformaldehyde, $10 \%(\mathrm{w} / \mathrm{v})$ sucrose in $0.1 \mathrm{M}$ sodium cacodylate buffer, $\mathrm{pH} 7.4$ for $12 \mathrm{~h}$, then washed and stored in $0.1 \mathrm{M}$ sodium cacodylate buffer, pH 7.4 containing $10 \%$ $(\mathrm{w} / \mathrm{v})$ sucrose at $4^{\circ} \mathrm{C}$ for $2 \mathrm{mo}$. They were postfixed in a mixture of $1 \%$ osmium tetroxide and $1.5 \% \mathrm{~K}_{3} \mathrm{Fe}(\mathrm{CN})_{6}$ for $1 \mathrm{~h}$, washed in Milli-Q water and dehydrated in an ethanol series, then transferred into $100 \%$ acetone and subsequently dried with hexamethyldisilazane $\left(\mathrm{C}_{6} \mathrm{H}_{19} \mathrm{NSi}_{2}\right)$. Several individuals were mounted on a stub and covered with a carbon film in an AGAR B7340 sputtercoater. The solenogastres were examined with a Phillips XL 20 SEM.

Transmission electron microsocpy (TEM). Three specimens of Helicoradomenia cf. acredema and 3 specimens of Helicoradomenia sp. 1 were collected from artificial settlement devices colleted in 2002, fixed, stored, and postfixed in the same way as the SEM speci- 
mens. After dehydration in an ethanol series up to $100 \%$, specimens were embedded in Spurr's epoxy resin (Spurr 1969). Sections were cut using a diamond knife on a Reichert Ultracut S microtome. Each individual was serial sectioned, alternating 100 semi-thin $(1 \mu \mathrm{m})$ sections with 10 ultra-thin $(75 \mathrm{~nm})$ sections. Semi-thin sections were stained with aquaeous $1.5 \%$ toluidine blue. Ultra-thin sections were contrasted with uranyl acetate and lead citrate in a Reichert LKB Stainer and then examined with a Zeiss EM 902 TEM.

Fluorescence in situ hybridization (FISH). Three specimens of Helicoradomenia sp. 1 were fixed in $100 \%$ ethanol. For decalcification they were rehydrated in 70,50, and $30 \%$ ethanol and transferred to $3 \%$ ascorbic acid in $0.3 \mathrm{M} \mathrm{NaCl}$ overnight. After dehydration in an ethanol series, the specimens were washed with the xylene substitute XEM-200 ( ${ }^{\mathrm{TM}}$ Sanova Diagnostik) and embedded in paraffin wax. Sections (4 $\mu \mathrm{m})$ were cut with a rotary microtome and mounted on gelatin-coated slides. To remove the paraffin prior to hybridization the slides were washed 3 times in 100\% xylene, then rehydrated with 96,80 , and $70 \%$ ethanol (each $10 \mathrm{~min})$, washed in $0.2 \mathrm{M} \mathrm{HCl}(12 \mathrm{~min})$ and rinsed in $0.02 \mathrm{M}$ Tris $/ \mathrm{HCl},(\mathrm{pH} 8 ; 10 \mathrm{~min})$. After treatment with $0.5 \mu \mathrm{g} \mathrm{ml}^{-1}$ Proteinase $\mathrm{K}\left(46^{\circ} \mathrm{C}, 5 \mathrm{~min}\right)$, slides were rinsed in $0.02 \mathrm{M}$ Tris $/ \mathrm{HCl}(\mathrm{pH} 8 ; 10 \mathrm{~min})$, postfixed with $4 \%$ paraformaldehyde (5 min), and rinsed in $0.02 \mathrm{M}$ Tris/ $\mathrm{HCl}$ ( $\mathrm{pH} \mathrm{8;} 10 \mathrm{~min})$.

Domain-specific olionucleotide probes for both Bacteria and Archaea, and phylum-specific olionucleotide probes for Bacteria were used in a hierarchical way to narrow the possible prokaryotic groups as far as possible. The probes were employed using different formamide concentrations to achieve accurate stringency during hybridizations (Table 1). All oligonucleotide probes were obtained from the Thermo Electron Corporation. Each probe was used in combination with the probe specific for Bacteria; thus, the Bacteria probe was applied at different formamide concentrations. The probe specific for Archaea was tested at concen- trations of 0,10 , and $20 \%$ formamide. A negative control with a nonsense probe (NONEUB) was included in every hybridization process.

Hybridization buffer (15 $\mu \mathrm{l} ; 5 \mathrm{M} \mathrm{NaCl}, 1 \mathrm{M}$ Tris/ $\mathrm{HCl}$, $\mathrm{pH} 8,10 \%$ sodium dodecyl sulfate and 20 or $35 \%$ formamide) mixed with $1.5 \mu \mathrm{l}$ specific oligonucleotide probe [50 ng $\mathrm{ul}^{-1}$ ] were applied on each tissue section. Each slide was incubated in a humid chamber in the dark at $46^{\circ} \mathrm{C}$ for $4 \mathrm{~h}$. To remove unbound oligonucleotide probes, slides were rinsed with washing buffer (5 M NaCl, $1 \mathrm{M}$ Tris $/ \mathrm{HCl}, \mathrm{pH}$ 8, $10 \%$ sodium dodecyl sulfate, $0.5 \mathrm{M}$ EDTA) in the dark at $48^{\circ} \mathrm{C}$ for $15 \mathrm{~min}$ and then briefly rinsed in Milli-Q water $\left(4^{\circ} \mathrm{C}\right)$. Slides were air dried and mounted in anti-fading glycerol medium (Citifluor AF2, Citifluor). Fluorescence images were acquired with a Zeiss LSM 510 Meta confocal laser scanning microscope.

\section{RESULTS}

Both Helicoradomenia cf. acredema and Helicoradomenia sp. 1 were approximately $3 \mathrm{~mm}$ long. $H$. cf. acredema had long, thin spicules, which gave the mollusk a furry appearance (Fig. 1a). The spicules of Helicoradomenia sp. 1 were shorter and bulkier so that this species looked less furry, and rather sleek (Fig. 1b). All individuals examined of both species possessed prokaryotes on their body surface (Fig. 1c-f) that were distributed along the entire body. The prokaryote density varied, although no specific patterns were discerned. Overall however, the prokaryote density of Helicoradomenia sp. 1 was higher than on $H$. acredema.

The cells on the surfaces of the solenogasters had the ultrastructural characteristics of prokaryotes (e.g. lack of nuclei) when observed with TEM (Fig. 2). Further, TEM investigations of both species revealed that the prokaryotes were not only located on the mollusks' surface but also within the entire cuticle (Fig. 2a).

Table 1. Oligonucleotide probes used for fluorescence in situ hybridization (FISH)

\begin{tabular}{|c|c|c|c|c|c|}
\hline Probe & Specificity & Probe sequence $\left(5^{\prime}-3^{\prime}\right)$ of probe & Target site & $\begin{array}{l}\text { Formamide } \\
\text { conc. used (\%) }\end{array}$ & Source \\
\hline EUB 338 & Bacteria & GCTGCCTCCCGTAGGAGT & 16S rRNA & 20,35 & Amann et al. (1990) \\
\hline Arch915 & Archaea & GTGCTCCCCCGCCAATTCCT & 16S rRNA & $0,10,20$ & Stahl \& Amann (1991) \\
\hline ALF968 & $\alpha$-Proteobacteria & GGTAAGGTTCTGCGCGT & 16S rRNA & 20 & Neef (1997) \\
\hline BET42a & $\beta$-Proteobacteria & GCCTTCCCACTTCGTTT & 23S rRNA & 35 & Manz et al. (1992) \\
\hline GAM42a & $\gamma$-Proteobacteria & GCCTTCCCACATCGTTT & 23S rRNA & 35 & Manz et al. (1992) \\
\hline Delta495a & $\delta$-Proteobacteria & AGTTAGCCGGTGCTTCCT & 16S rRNA & 35 & Loy et al. (2002) \\
\hline Delta495b & $\delta$-Proteobacteria & AGTTAGCCGGCGCTTCCT & 16S rRNA & 35 & Loy et al. (2002) \\
\hline Delta495c & $\delta$-Proteobacteria & AATTAGCCGGTGCTTCCT & 16S rRNA & 35 & Loy et al. (2002) \\
\hline CF319a & Cytophaga/Flavobacter & TGGTCCGTGTCTCAGTAC & 16S rRNA & 35 & Manz et al. (1996) \\
\hline NONEUB & Control probe & ACTCCTACGGGAGGCAGC & 16S rRNA & $0,10,20,35$ & Wallner et al. (1993) \\
\hline
\end{tabular}



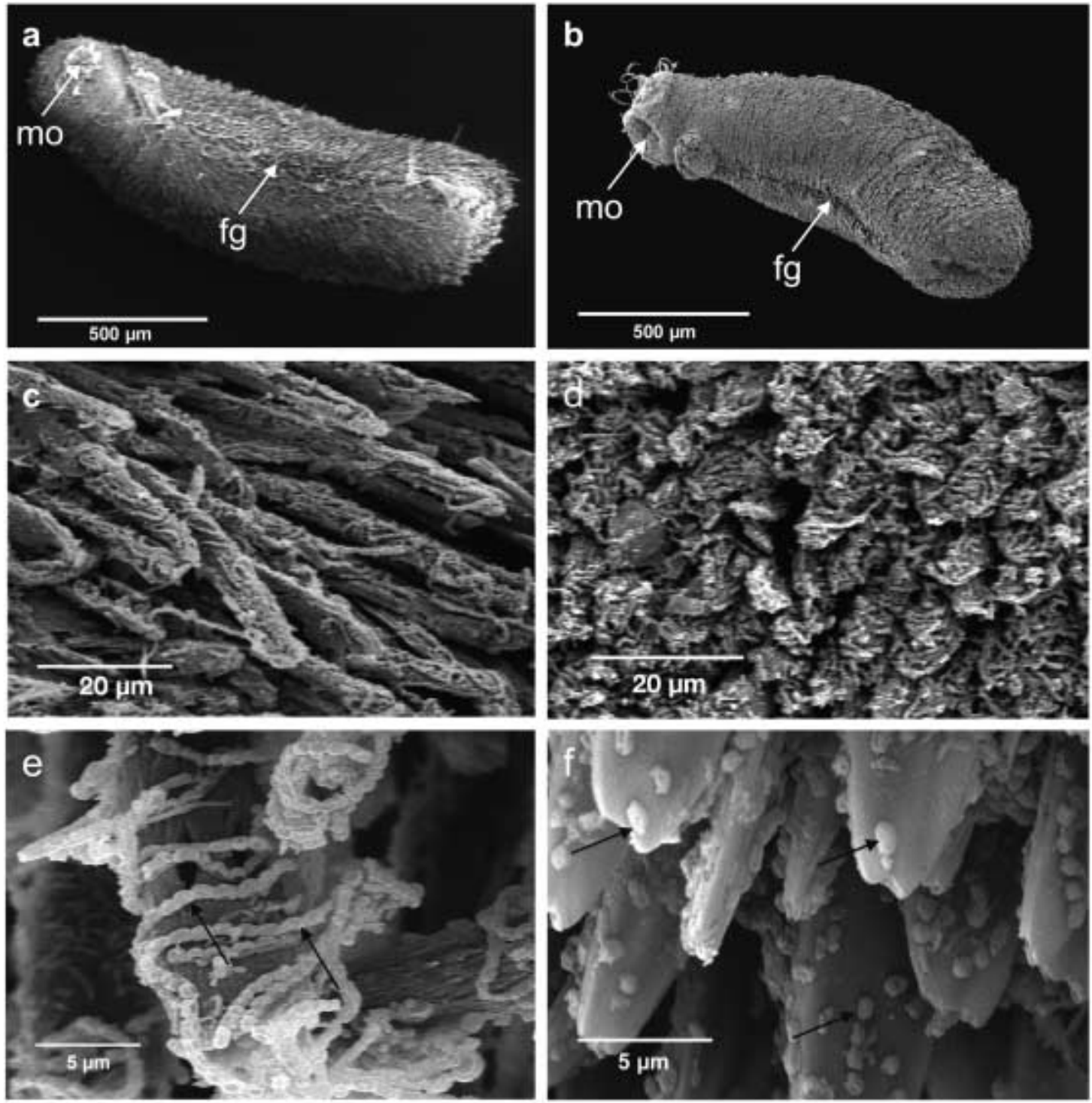

Fig. 1. Scanning electron micrographs (SEM) of Helicoradomenia cf. acredema, Helicoradomenia sp. 1, their bacterial cover and 2 examples of their morphotypes. (a) H. cf. acredema, ventral view. fg: foot groove: mo: mouth opening. (b) Helicoradomenia sp. 1 ventrolateral view. fg: foot groove; mo: mouth opening. (c) Bacterial cover on spicules of $H$. cf. acredema. (d) Bacterial cover on spicules of Helicoradomenia sp. 1. (e) Bacterial chains (arrows) on spicules of $H$. cf. acredema. (f) Individually scattered bacteria (arrows) on spicules of Helicoradomenia sp. 1

Using a series of alternating semi-thin and ultra-thin sections, no accumulation of prokaryotes at any particular host regions was found. Most of the prokaryotic morphotypes occurred on and in the entire cuticle as well as on the spicules. The endocuticular microbes were either isolated or arranged in irregular clusters and were often found to surround the spicules (Fig. 2a). Even in the dorsoterminal sense organ extraand endocuticular prokaryotes were observed (data not shown). Since this organ is folded inwards, the microbes appeared to be located inside the host although actually they were on the exterior.
Both mollusk species hosted several similar prokaryote morphotypes (Figs. 1e,f \& 2d-k). Four different basic types were identified: (1) rods (Fig. $2 \mathrm{~d}-\mathrm{f}, \mathrm{h}$ ), (2) helical prokaryotes (Fig. 2j), (3) unsheathed trichomes (Fig. 2g), and (4) sheathed trichomes (Fig. 2k). All exhibited an outer and a cytoplasmic membrane, typical for gram-negative bacteria. Divisional stages were detected among all types. The different morphotypes occurred mingled in all body regions.

Rod-shaped prokaryotes were the most frequent morphotype found on both Helicoradomenia species and occurred either individually (Fig. 1f), in irregular 

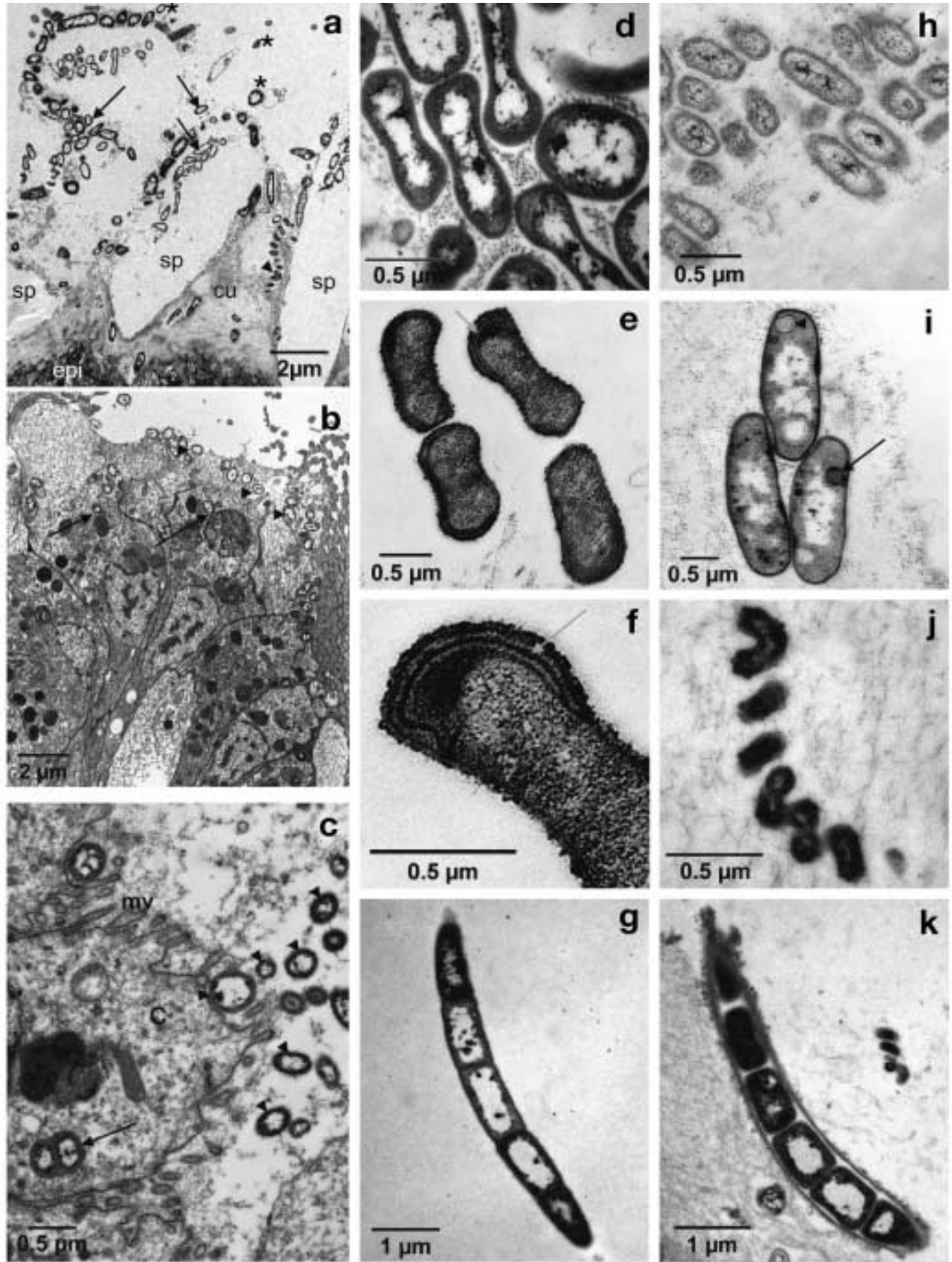

Fig. 2. Transmission electron micrographs (TEM) of different sections of Helicoradomenia cf. acredema and Helicoradomenia sp. 1 and their bacteria. (a) Overview of bacterial morphotypes and arrangements on and within the cuticle of Helicoradomenia sp. 1. cu: cuticle; epi: epidermis; sp: space where spicules were located before TEM treatment; arrows: rods; arrowhead: helical bacteria; asterisks: epibionts. (b) Overview of bacteria between cilia and within cells of Helicoradomenia sp. 1. Arrows: bacteria within cells; arrowheads: bacteria outside of host cells. (c) Close-up of bacteria within and close to epidermal cells of Helicoradomenia sp. 1. Arrows: bacteria within cells; arrowheads: bacteria outside of host cells; c: cytoplasma; mv: microvilli. (d) Electrondark rod-shaped bacteria within the cuticle of Helicoradomenia sp. 1. (e) Rod-shaped bacteria with rippled cell membrane, high ribosome density and elongated internal membranes at the cell margin within the cuticle of Helicoradomenia sp. 1. (f) Detail of (e), intracytoplasmic membranes (arrow) at the periphery of the cytoplasm. (g) Unsheathed trichome within the cuticle of Helicoradomenia sp. 1. (h) Electron-light rod-shaped bacteria in the cuticle of Helicoradomenia sp. 1. (i) Rod-shaped bacteria with electron-dense (arrow) and electron-light (arrowhead) inclusions within the cuticle of Helicoradomenia sp. 1. (j) Helical bacteria within the cuticle of $H$. cf. acredema. (k) Sheathed trichome within the cuticle of $H$. cf. acredema 
clusters (Fig. 2a) or arranged in chains (Fig. 1e). Their diameter varied between 0.2 and $0.8 \mu \mathrm{m}$, and they could reach a length of 2 to 5 times the diameter. Cells with electron-dark (Fig. 2d) and electron-light cytoplasm (Fig. 2h) were observed which lacked conspicuous ultrastructural features. Electron-light rods were often encircled by electron-dense rods (Fig. 2a). Another rod-shaped type contained similar-sized, membrane-bound vesicles with varying electron density distributed in electron-light cytoplasm (Fig. 2i). Forms with a rippled cell surface, with ribosomes evenly distributed across the whole cell and elongated internal membranes at the cell margin (Fig. 2e,f), were observed.

The helical prokaryotes (Fig. 2j) varied in length, number, and tightness of revolutions. Their estimated length ranged from 1.5 to $3 \mu \mathrm{m}$, while their spiral revolutions exhibited steps of 0.2 to $0.4 \mu \mathrm{m}$. The helical prokaryotes were not as common as rods, but more numerous than trichomes.

Both types of trichomes occurred individually and were relatively rare. Unsheathed trichomes (Fig. 2g) consisted of several cells with a diameter of 0.3 to $1.20 \mu \mathrm{m}$ with variable lengths between 1 and 2 cell diameters. These trichomes were often slightly constricted at the cell septa. The sheathed trichomes (Fig. 2k) consisted of several cells with a diameter of 0.6 to $1 \mu \mathrm{m}$ and a variable length between 1 and 2 cell diameters. The cells were more or less clearly separated, but enclosed in a common sheath.

Although the majority of the prokaryotes were located on and within the cuticle in both mollusk species, in Helicoradomenia sp. 1, rod-shaped prokaryotes were discovered located inside epidermal cells (Fig. 2b,c). These prokaryotes were not surrounded by a host membrane but were dispersed freely in the host cytoplasm. The epidermal cells hosting prokaryotes were restricted to the area of ventral papillae at the posterior end of the mollusk. One to 2 prokaryotes per host cell were counted in individual sections.

The use of phylogenetic group probes and FISH allowed identification of different prokaryote phylogenetic groups. All of the prokaryotes associated with Helicoradomenia. sp. 1 hybridized with the EUB338 probe, specific for the domain Bacteria, and none with the Arch915 probe, specific for the domain Archaea (data not shown). No signal was obtained for probes specific for the $\beta$-Proteobacteria (BET42a), $\delta$-Proteobacteria (Delta495a, Delta495b, Delta495c), and Cytophagales/Flavobacter (CF319a) (results not shown). Using probes specific for the $\alpha$-Proteobacteria (ALF968) and the $\gamma$-Proteobacteria (GAM42a), some of the bacteria could be identified as such (Fig. 3). Visually, however, a large portion of those cells hybridizing with the Bacteria domain probe did not hybri- dize with any of the probes for the subgroups tested and therefore remained unidentified (data not shown).

$\alpha$-Proteobacteria (Fig. 3a) made up the largest portion of the identified Bacteria, whereas the $\gamma$-Proteobacteria-probe labeled only a few of the solenogastres bacteria. None of the bacterial morphotypes could be attributed to only one of the phylogenetic groups, as both $\alpha$-Proteobacteria and $\gamma$-Proteobacteria probes hybridized with rods as well as sheathed and unsheathed trichomes (Fig. 3b,c,e,f). However, most of the $\gamma$-Proteobacteria were sheathed and unsheathed trichomes (Fig. 3c,f). Helical bacteria did not hybridize with any group-specific probe except for EUB338 probe (data not shown).

\section{DISCUSSION}

Here we describe, for the first time in detail, the presence of a symbiotic bacterial association within the class Solenogastres. To date only in 1 species of solenogasters, Neomenia carinata, has a bacterial association been mentioned. In the latter case the sole known fact is that bacteria are associated with the brush border and are engulfed by mantle epithelium (Scheltema et al. 1994). However, we have shown that 2 species of the genus Helicoradomenia, H. cf. acredema and an as yet undescribed co-occurring species Helicoradomenia sp. 1 from the same hard substrate deep-sea vent habitat, harbor epi- and endocuticular bacteria. The fact that the same microbial morphotypes occurred consistently on all 3 individuals examined of both host species strongly suggests that these specimens do not represent isolated cases. The vast majority of the bacteria appeared intact and many were dividing, which further indicates that these associations are well established for these 2 solenogasters species. Further, all specimens $(\sim 100)$ were white in color, suggesting thioautotrophs were present. We infer that these are symbiotic associations, according to De Bary (1879) the living together of differently named organisms over a longer time period.

The distribution of Helicoradomenia at the East Pacific Rise appears to range from low to moderate diffuse vent flow environments with ambient deep-sea to slightly elevated temperatures. We have recovered both species studied from siboglinid tubeworm Riftia pachypila aggregations (present study) as well as from inactive sulfide chimneys ( $\mathrm{M}$. Bright pers. obs.). In addition, species of Helicoradomenia were also found in clam Calyptogena magnifica Boss and Turner, 1980 and mussel Bathymodiolus thermophilis Kenk and Wilson, 1985 beds, and form a small but constant component of the deep-sea hydrothermal vent fauna (Scheltema 2000, Van Dover 2002). All of these tubeworms, 

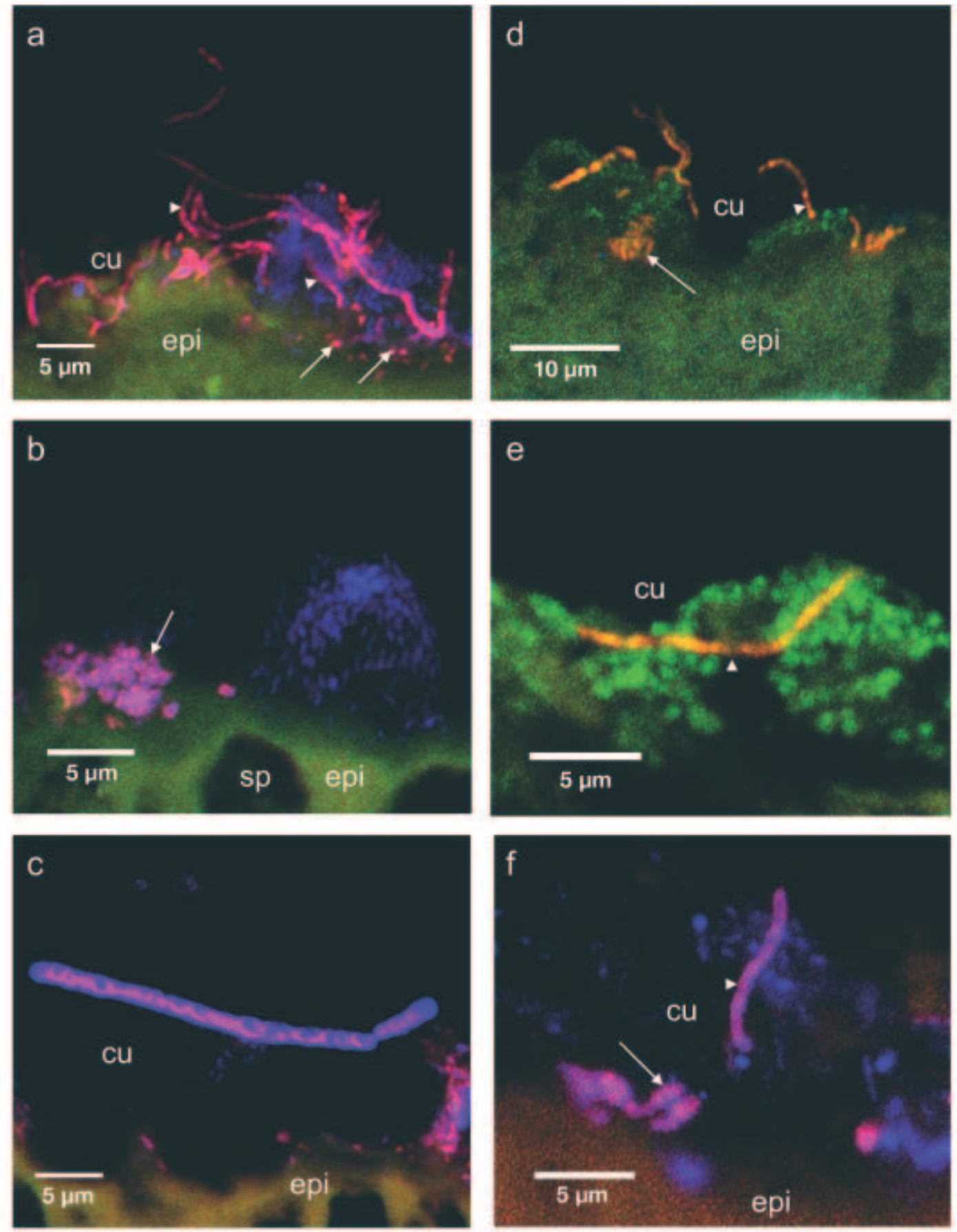

Fig. 3. Fluorescence in situ hybridization (FISH) photographs of paraffin sections of Helicoradomenia sp. 1 showing the variety of endocuticular symbionts; note that the cuticle shows no autofluorescence but extends over the entire upper parts of micrographs, while the epidermis tissue is highly autofluorescent. Overlap of Cy3-labeled probes with Cy5-labeled probes results in pink color; overlap of Cy3-labeled probes with fluoresein-labeled probes results in yellow to orange color, depending on individual signal intensities. Selected images are representative for all body regions. (a) Overview of differently shaped $\alpha$-Proteobacteria (pink overlap, Cy3-labeled), other Bacteria (blue, Cy5-labeled). Arrows: rods; arrowheads: trichomes; cu: cuticula; epi: epidermis. (b) Rod-shaped $\alpha$-Proteobacteria (pink overlap, Cy3-labeled), other Bacteria (blue, Cy5-labeled). epi: epidermis; sp: spicule location. (c) Filamentous $\alpha$-Proteobacteria (pink overlap, Cy3-labeled), other Bacteria (blue, Cy5-labeled). cu: cuticula; epi: epidermis. (d) Overview of differently shaped $\gamma$-Proteobacteria (orange overlap, Cy3-labeled), other Bacteria (green, fluoresceinlabeled). Arrows: rods; arrowheads: trichomes; cu: cuticula; epi: epidermis. (e) Filamentous $\gamma$-Proteobacteria (orange overlap, Cy3-labeled), other Bacteria (green, fluorescein-labeled). cu: cuticule. (f) Overview of differently shaped $\gamma$-Proteobacteria (pink overlap, Cy3-labeled), other Bacteria (blue, Cy5-labeled). Arrows: rods; arrowheads: trichomes; cu: cuticula; epi: epidermis 
clams, and mussels host thioautotrophic endosymbionts, which thrive on the sulfidic vent flux. Thus, Helicoradomenia spp. are exposed to this source, since they share the same habitat.

In some of the symbionts of Helicoradomenia, especially the rods with a rippled cell surface, the high density of ribosomes and internal membranes along the cell margin (Fig. 2h) are outstanding. According to Oeschger \& Schmaljohann (1988) the rippled appearance of the cell surface results from an undulating cell wall; however, it is also possible that this is a fixation artifact. The internal membranes of these bacteria point to the occurrence of type II methanotrophs, which are characterized by intracytoplasmic membranes arranged in concentric rings at the periphery of the cytoplasm (Nelson \& Fisher 1995). Methane is also a prominent component of hydrothermal vent fluid (Van Dover 2000, Von Damm \& Lilley 2004), and dual symbioses including thioautotrophic as well as methanotrophic endosymbionts within the same mussel host have already been described (Cavanaugh et al. 1992, Fiala-Médioni et al. 2002, DeChaine \& Cavanaugh 2006).

Gram-negative rods were the most common morphotypes observed in TEM sections of the 2 Helicoradomenia species. However, the possibility cannot be ruled out that a significant number of epibionts were lost during fixation and embedding procedures. The phylogenetic identity of the helical bacteria remains to be determined. Although the helical bacteria are corkscrew-shaped, they lack axial filaments between their outer sheath and the cell wall and may not be true spirochetes. They are unlikely to be related to the genus Spirillum, since $\beta$-Proteobacteria could not be detected among the epibionts. Unsheathed and sheathed trichomes are common members of the epibiotic communities on Halicryptus spinulosus, Alvinella pompejana, and Rimicaris exoculata. However, for the latter 2 associations it is known that these filamentous bacteria belong to the $\varepsilon$-Proteobacteria (Haddad et al. 1995, Polz \& Cavanaugh 1995, Cary et al. 1997).

Interestingly, FISH revealed that the majority of the identified symbionts belong to the $\alpha$-Proteobacteria with fewer $\gamma$-Proteobacteria detected. Most ectosymbionts from hydrothermal vent invertebrates characterized by $16 \mathrm{~S}$ rRNA phylogeny so far belong to the $\varepsilon$-Proteobacteria. In contrast, thioautotrophic endosymbionts of tubeworms, clams, and mussels from the same environments, to date, exclusively harbor $\gamma$-Proteobacteria (McMullin et al. 2003, Cavanaugh et al. 2006). However, while type I methanotrophs sequenced from hydrothermal vent symbiosis so far cluster with free-living $\gamma$-Proteobacteria (DeChaine \& Cavanaugh 2006) type II methanotrophs fall within the $\alpha$-Proteobacteria (Tsuji et al. 1990, Hanson et al. 1993).
Thus, our FISH results are consistent with our previous prediction that thioautotrophic as well as methanotrophic bacteria could be part of the symbiotic community associated with Helicoradomenia sp. 1.

To date no group-specific probes for the $\varepsilon$-Proteobacteria exist (M. Wagner pers. comm.); therefore, the affiliation of the symbionts on Helicoradomenia sp. 1 with this bacterial clade could not be tested. The fact that $\varepsilon$-Proteobacteria either make up the whole symbiont community in ectosymbioses from deep-sea hydrothermal vents, or are at least part of it, suggests that some of the unidentified Bacteria on Helicoradomenia sp. 1 might also belong to this bacterial clade. Also, small numbers or inaccessibility of the target molecule can result in low or no FISH signals, thus under-representing the true abundance of bacteria (Amann et al. 1995). Therefore, further characterization, including 16SrRNA sequence analyses, will be needed to confirm our results and to determine the so far unidentified Bacteria.

The bacteria found on Helicoradomenia cf. acredema and Helicoradomenia sp. 1 were not associated with a specific region of the host bodies. Similar to the shallow-water priapulid Halicryptus spinulosus von Siebold, 1849 multi-partner association (Oeschger \& Schmaljohann 1988) a morphologically diverse microbial community was found on the entire cuticle of $H$. cf. acredema and Helicoradomenia sp. 1. In contrast, the bacteria on the solenogaster Neomenia carinata was restricted to the area of the mantle cavity (Scheltema et al. 1994). A similar symbiotic association exists in Laevipilina antarctica, an Antarctic Monoplacophora, with different types of bacteria found under the glycocalyx between the microvilli of specific body regions (Haszprunar et al. 1995). Also, in most known ectosymbioses from other hydrothermal vent invertebrates, the symbionts are located only on certain body regions or appendages. The majority of symbionts on Alvinella pompejana are associated with dorsal epidermal expansions (Desbruyères et al. 1998), and on Rimicaris exoculata the ectosymbionts are located inside the carapace and on their extremities (Polz \& Cavanaugh 1995). Only the ciliate Zoothamnium niveum (Hemprich and Ehrenberg, 1831) Ehrenberg, 1838 from sulfidic mangrove peat in tropical to subtropical shallow waters and most of the Stilbonematinae, a subfamily of marine nematodes, from temperate to tropical shallowwater sulfidic sediments, are almost entirely covered by their bacterial symbionts. In these shallow-water symbioses, both strict 2-partner associations as well as some stilbonematid species with multiple bacterial types are found (Ott et al. 2004a,b).

In many known ectosymbioses involving thioautotrophs the symbionts are located exclusively on the hosts' exteriors, forming a layer on the host surfaces 
but not penetrating the cuticle or epidermis (Oeschger \& Schmaljohann 1988, Oeschger \& Janssen 1991, Polz \& Cavanaugh 1995, Desbruyères et al. 1998). However, in Helicoradomenia the bacteria are embedded in the cuticle of the mollusk (Fig. 2a). Similarly, the filamentous epibacteria of the oligochaete Tubificoides benedii (d'Udekum, 1855) are embedded in the cuticle of the posterior segments of the worm (Dubilier 1986). In thyasirids, extracellular endosymbionts are present between the epidermal cell membrane and the cuticle; however, these bacteria are not embedded in the cuticle but subcuticular (Southward 1986).

In Helicoradomenia sp. 1 bacterial cells were also found within epidermal cells of the mollusk (Fig. 2b,c). This condition of bacteria on the mollusk surface, within the cuticle and inside some of the epidermal cells concurrently within one individual, could represent a transitional stage between ecto- and endosymbiosis. Also, in the ciliate Kentrophoros latum ectosymbiotic sulfur bacteria and spirochaetes together with intracellular prokaryote symbionts of unknown function are found (Raikov 1974, Fenchel \& Finlay 1989).

Whether the solenogasters gain any advantage by harboring such a diverse epiflora remains unclear. For a number of ectosymbioses including Zoothamnium niveum (Bauer-Nebelsick et al. 1996), Rimicaris exoculata (Polz et al. 1998) and several species of Stilbonematinae (Ott \& Novak 1989, Riemann et al. 2003) it is known that the symbionts are a source of nutrition for their hosts. However, species of Helicoradomenia have a functional digestive tract and are able to ingest small prey; thus, they are considered to be scavengers (Scheltema 2000, Todt 2004). Further, it seems unlikely that the bacteria serve as a source of nutrition for their hosts as bacteria or bacterial fragments were never found in the guts of $H$. cf. acredema and Helicoradomenia sp. 1. (Todt 2004).

The benefits for the bacteria are apparent. First, the mollusk's cuticle with its embedded spicules provides a complex structured habitat with an increased surface area well suited for the settlement of bacteria. Second, the epibiotic bacteria might profit by being transported by their host to inorganic and organic compounds from the hydrothermal vents, which they can use as a source of nutrition. Third, the bacteria may derive some nourishment from the host. The epidermis of Solenogastres is rich in secretory cells, which discharge to the outside (Scheltema et al. 1994). Thus, the bacteria may be able to feed on the secreted compounds of the solenogasters. Since the symbionts are located within the cuticle, this suggests that at least some of the bacteria are able to degrade chitin, a metabolic capability known for many $\gamma$ - and $\alpha$-Proteobacteria (Cottrell et al. 2000).

In conclusion, we describe here a new symbiotic association found between diverse bacteria and
Solenogastres from hydrothermal vents. A unique feature of this association is the occurrence of both epibiotic and endocuticular bacteria on and within the same organism. The majority of the symbiotic bacteria belonged to the $\alpha$-Proteobacteria, while $\gamma$-Proteobacteria also were identified in Helicoradomenia sp. 1. However, their functional and ecological role is not yet understood and further studies are needed to identity the additional bacteria and to determine the roles and benefits accrued to the partners in these solenogastres-bacteria associations.

Acknowledgements. This research was supported by the Austrian Science Foundation, P13762-B03 and \# P16774-B03 (to M.B.) and by the United States National Science Foundation NSF-CE 0002460 (to C.M.C.), which we gratefully acknowledge. We thank the chief scientist of the cruise C. R. Fisher for kindly inviting M.B. and for his continuous support, the captains and crews of the RV 'Atlantis' and DSV 'Alvin' for their able assistance in sample collections. We also thank W. Klepal, D. Gruber and G. Spitzer (Department of Cell Imaging and Ultrastructure, University of Vienna) and $M$. Wagner, M. Horn, and K. Stöcker (Department of Microbial Ecology, University of Vienna), P. Gahleitner, A. D. Nussbaumer, C. Rinke (Department of Marine Biology, University of Vienna) and H. Katz for their support and technical assistance and L. von Salvini-Plawen and C. Todt for identification and valuable discussions on Solenogastres.

\section{LITERATURE CITED}

Amann RI, Binder BJ, Olson RJ, Chisholm SW, Devereux R, Stahl DA (1990) Combination of 16S rRNA-targeted oligonucleotide probes with flow cytometry for analyzing mixed microbial populations. Appl Environ Microbiol 56: 1919-1925

Amann RI, Ludwig W, Schleifer KH (1995) Phylogenetic identification and in situ detection of individual microbial cells without cultivation. Microbiol Rev 59(1):143-169

Bauer-Nebelsick M, Bardele CF, Ott JA (1996) Electron microscopic studies on Zoothamnium niveum (Hemprich \& Ehrenberg, 1831) Ehrenberg 1838 (Oligohymenomorpha, Peritrichida), a ciliate with ectosymbiotic, chemoautotrophic bacteria. Eur J Protistol 32:202-215

Beedham GE, Trueman ER (1968) The cuticle of the Aplacophora and its evolutionary significance in the Mollusca. J Zool 154:443-451

Bright M, Giere O (2005) Microbial symbiosis in Annelida. Symbiosis 38:1-45

Campbell BJ, Cary SC (2001) Characterization of a novel spirochete associated with the hydrothermal vent polychaete annelid, Alvinella pompejana. Appl Environ Microbiol 67(1):110-117

Campell BJ, Jeanthon C, Kostka JE, Luther GW III, Cary SC (2001) Growth and phylogenetic properties of novel bacteria belonging to the epsilon subdivision of the Proteobacteria enriched from Alvinella pompejana and deep-sea hydrothermal vents. Appl Environ Microbiol 67(10): 4566-4572

Cary SC, Cottrell MT, Stein JL, Camacho F, Desbruyères D (1997) Molecular identification and localization of filamentous symbiotic bacteria associated with the hydrother- 
mal vent annelid Alvinella pompejana. Appl Environ Microbiol 63(3):1124-1130

Cavanaugh, CM, Gardiner SL, Jones ML, Jannasch HW, Waterbury JB (1981) Prokaryotic cells in the hydrothermal vent tube worm Riftia pachyptila Jones: possible chemoautotrophic symbionts. Science 213:340-342

Cavanaugh CM, Wirsen CO, Jannasch HW (1992) Evidence for a methylotrophic symbionts in a hydrothermal vent mussel (Bivalvia: Mytilidae) from the Mid-Atlantic Ridge. Appl Environ Microbiol 58(12):3799-3803

Cavanaugh CM, McKiness ZP, Newton ILG, Steward FJ (2005) Marine chemosynthetic symbioses. In: Dworkin M, Falkow S, Rosenberg E, Schleifer KH, Stackebrandt E (eds) The Prokaryotes: an evolving electronic resource for the microbiological community. Release 3.20. SpringerVerlag, New York. http://link.springer-ny.com/link/service/ books/10125

Corliss JB, Dymond J, Gordon LI, Edmond JM and 7 others (1979) Submarine thermal springs on the Galápagos Rift. Science 203:1073-1083

Cottrell MT, Wood DN, Yu L, Kirchman DL (2000) Selected chitinase genes in cultured and uncultured marine bacteria in the $\alpha$ - and $\gamma$-subclasses of the Proteobacteria. Appl Environ Microbiol 66(3):1195-1201

De Bary A (1879) Die Erscheinung der Symbiose. Verlag von Karl J. Trubner, Strassburg

DeChaine EG, Cavanaugh CM (2006) Symbioses of methonotrophs and deep-sea mussels (Mytilidae: Bathymodiolinae). In: Overman J (ed) Molecular basis of symbiosis. Progress in molecular and subcellar biology, Vol 41. Springer-Verlag, Berlin, p 227-249

Desbruyères $\mathrm{D}$, Chevaldonné $\mathrm{P}$, Alayse $\mathrm{AM}$, Jollivet $\mathrm{D}$ and 14 others (1998) Biology and ecology of the 'Pompeii worm' (Alvinella pompejana Desbruyères and Laubier), a normal dweller of an extreme deep-sea environment: a synthesis of current knowledge and recent developments. DeepSea Res II 45:383-422

Dubilier N (1986) Association of filamentous epibacteria with Tubificoides benedii (Oligochaeta: Annelida). Mar Biol 92: 285-288

Felbeck H (1981) Chemoautotrophic potential of the hydrothermal vent tube worm, Riftia pachyptila Jones (Vestimentifera). Science 213:336-338

Fenchel T, Finlay B (1989) Kentrophoros: a mouthless ciliate with a symbiotic kitchen garden. Ophelia 30(2):75-93

Fiala-Médioni A, McKiness ZP, Dando P, Boulegue J, Mariotti A, Alayse-Danet AM, Robinson JJ, Cavanaugh CM (2002) Ultrastructural, biochemical, and immunological characterization of two populations of the mytilid mussel Bathymodiolus azoricus from the Mid-Atlantic Ridge: evidence for a dual symbiosis. Mar Biol 141:1035-1043

Goffredi SK, Warèn A, Orphan VJ, Van Dover CL, Vrijenhoek RC (2004) Novel forms of structural integration between microbes and a hydrothermal vent gastropod from the Indian Ocean. Appl Environ Microbiol 70(5):3082-3090

Haddad A, Camacho F, Durand P, Cary SC (1995) Phylogenetic characterization of the epibiotic bacteria associated with the hydrothermal vent polychaete Alvinella pompejana. Appl Environ Microbiol 61(5):1679-1687

Hanson RS, Bratina BJ, Brusseau GA (1993) Phylogeny and ecology of methylotrophic bacteria. In: Murrell JC, Kelly DP (eds) Microbial growth on $C_{1}$ compounds. Intercept, Andover, p 285-302

Haszprunar G, Schaefer K, Warén A, Hain S (1995) Bacterial symbionts in the epidermis of an Antarctic neopilinid limpet (Mollusca, Monoplacophora). Phil Trans R Soc Lond B 347:181-185
Krieger J, Giere O, Dubilier N (2000) Immunocytochemical localization of RubisCo in endosymbiotic bacteria of the gutless oligochaete Inandrilus leukodermatus (Annelida). Mar Biol 137:239-244

Lonsdale P (1977) Clustering of suspension-feeding macrobenthos near abyssal hydrothermal vents at oceanic spreading centers. Deep-Sea Res 24(9):857-858

Loy A, Lehner A, Lee N, Adamczyk J, Meier H, Ernst J, Schleifer KH, Wagner M (2002) Oligonucleotide microarray for 16S rRNA gene-based detection of all recognized lineages of sulfate-reducing prokaryotes in the environment. Appl Environ Microbiol 68:5064-5081

Manz W, Amann R, Ludwig W, Wagner M, Schleifer KH (1992) Phylogenetic oligodeoxynucleotide probes for the major subclasses of Proteobacteria: problems and solutions. Syst Appl Microbiol 15:593 -600

Manz W, Amann R, Ludwig W, Vancanneyt M, Schleifer KH (1996) Application of a suite of 16S rRNA-specific oligonucleotide probes designed to investigate bacteria of the phylum cytophaga-flavobacter-bacteroides in the natural environment. Microbiology 142:1097-1106

McMullin ER, Hourdez S, Schaeffer SW, Fisher CR (2003) Phylogeny and biogeography of deep sea vestimentiferan tubworms and their bacterial symbionts. Symbiosis 34:1-4

Neef A (1997) Anwendung der in situ Einzelzell-Identifizierung von Bakterien zur Populationsanalyse in komplexen mikrobiellen Biozönosen. PhD dissertation, Technische Universität München, Munich

Nelson DC, Fisher CR (1995) Chemoautotrophic and methanotrophic endosymbiotic bacteria at deep-sea hydrothermal vents and seeps. In: Karl DM (ed) The microbiology of deep-sea hydrothermal vents. CRC Press, Boca Raton, FL, p 125-167

Oeschger R, Janssen HH (1991) Histological studies on Halicryptus spinulosus (Priapulida) with regard to environmental hydrogen sulfide resistance. Hydrobiologia 222:1-12

Oeschger R, Schmaljohann R (1988) Association of various types of epibacteria with Halicryptus spinulosus (Priapulida). Mar Ecol Prog Ser 48:285-293

Ott J, Novak R (1989) Living at an interface: meiofauna at the oxygen-sulfide boundary of marine sediments. In: Ryland JS, Tyler PA (eds) Reproduction, genetics and distribution of marine organisms. Olsen \& Olsen, Fredensborg, p 415-422

Ott J, Bright M, Bulgheresi S (2004a) Marine microbial thiotrophic ectosymbiosis. Oceanogr Mar Biol Annu Rev 42:95-118

Ott J, Bright M, Bulgheresi S (2004b) Symbiosis between marine nematodes and sulfur-oxidizing chemoautotrophic bacteria. Symbiosis 36:103-1256

Peters W (1971) Occurrence of chitin in Mollusca. Comp Biochem Physiol 41B:541-550

Pflugfelder B, Fisher CR, Bright M (2005) The color of the trophosome: elemental sulfur distribution in the endosymbionts of Riftia pachyptila (Vestimentifera; Siboglinidae). Mar Biol 146:895-901

Polz MF, Cavanaugh CM (1995) Dominance of one bacterial phylotype at a Mid-Atlantic Ridge hydrothermal vent site. Proc Natl Acad Sci USA 92:7232-7236

Polz MF, Robinson JJ, Cavanaugh CM (1998) Trophic ecology of massive shrimp aggregations at a Mid-Atlantic Ridge hydrothermal vent site. Limnol Oceanogr 43(7):1631-1638

Raikov IB (1974) Étude ultrastructurale des bactéries épizoiques et endozoiques de Kentrophoros latum Raikov, cilié holotriche mésopsammique. Cah Biol Mar 15:379-393

Riemann F, Thiermann F, Bock L (2003) Leptonemella species (Desmodoridae, Stilbonematinae) benthic marine nemato- 
des with ectosymbiotic bacteria, from littoral sand of the North Sea island Sylt. Taxonomy and ecological aspects. Helgol Mar Res 57:118-131

Scheltema AH (1991) Helicoradomenia juani gen. et sp. nov., a Pacific hydrothermal vent Aplacophora (Mollusca: Neomeniomorpha). Veliger 34(2):195-203

Scheltema AH (2000) Two new hydrothermal vent species, Helicoradomenia bisquama and Helicoradomenia acredema, from the eastern Pacific ocean (Mollusca, Aplacophora). Argonauta XIV(2):15-25

Scheltema AH, Tscherkassky M, Kuzirian AM (1994) Aplacophora. In: Harrison FW (ed) Microscopic anatomy of invertebrates. Mollusca, Vol 5. Wiley-Liss, New York, p 13-54

Southward EC (1986) Gill symbionts in thyasirids and other bivalve molluscs. J Mar Biol Assoc UK 66:889-914

Spurr AR (1969) A low-viscosity epoxy resin embedding medium for electron microscopy. J Ultrastruct Mol Struct Res 26:31-43

Stahl DA, Amann R (1991) Development and application of nucleic acid probes. In: Stackebrandt E, Goodfellow M (eds) Nucleic acid techniques in bacterial systematics. John Wiley \& Sons, Chichester, p 205-248

Todt C, Salvini-Plawen L (2005) The digestive tract of Helicoradomenia (Solenogastres, Mollusca), aplacophoran molluscs from the hydrothermal vents of the East Pacific Rise. Invertebr Biol 124(3):230-253

Editorial responsibility: Otto Kinne (Editor-in-Chief), Oldendorf/Luhe, Germany
Tsuji K, Tsien HC, Hanson RS, DePalma SR, Scholtz R, LaRoche $S$ (1990) 16S ribosomal RNA sequence analysis for determination of phylogenetic relationship among methylotrophs. J Gen Microbiol 136:1-10

Urakawa H, Dubilier N, Fujiwara Y, Cunningham DE, Kojima S, Stahl DA (2005) Hydrothermal vent gastropods from the same family (Provannidae) harbour $\varepsilon$ - and $\gamma$-protobacterial endosymbionts. Environ Microbiol 7(5):750-754

Van Dover CL (2000) The ecology of deep-sea hydrothermal vents. Princeton University Press, Princeton, NJ

Van Dover CL (2002) Community structure of mussel beds at deep-sea hydrothermal vents. Mar Ecol Prog Ser 230: 137-158

Van Dover CL, Humphris SE, Fornari D, Cavanaugh CM and 23 others (2001) Biogeography and ecological settings of Indian Ocean hydrothermal vents. Science 294:818-823

Von Damm KL, Lilley MD (2004) Diffuse flow hydrothermal fluids from 9 50' N East Pacific Rise: origin, evolution and biogeochemical controls. In: Wilcock WSD, Delong EF, Kelley DS, Baross JA, Cary SC (eds) The subseafloor biosphere at mid-ocean ridges. AGU Monograph 144. American Geographical Union, Washington, DC, p 243-266

Wallner G, Amann R, Beisker W (1993) Optimizing fluorescent in situ hybridization with rRNA-targeted oligonucleotide probes for flow cytometric identification of microorganisms. Cytometry 14:136-143

Submitted: July 28, 2005; Accepted: January 24, 2006 Proofs received from author(s): July 26, 2006 